\title{
High-attenuation mucus in a patient with allergic bronchopulmonary aspergillosis
}

\author{
Sachiho Inada, Hiroshi Sugimoto 두, Tomomi Terashita, Kyosuke Nakata
}

Department of Respiratory Medicine, Konan Medical Center, Kobe, Hyogo, Japan

\section{Correspondence to Dr Hiroshi Sugimoto; dr.sugimoto@gmail.com}

Accepted 23 September 2021

\section{DESCRIPTION}

A 63-year-old Japanese woman presented with a 9-month history of productive cough. Although she had been treated with oral antibiotics (amoxicillin and levofloxacin), her symptoms worsened. She had no history of allergic diseases, including asthma, except for known allergies to eggs. She had never smoked.

Her vital signs and physical examination were unremarkable. Laboratory tests revealed white blood cell count of $12.26 \times 10^{9} / \mathrm{L}$ (normal: $3.3-8.6 \times 10^{9} / \mathrm{L}$ ) with absolute eosinophil count of $2.45 \times 10^{9} / \mathrm{L}$ (normal: $0.10-0.30 \times 10^{9} / \mathrm{L}$ ), serum total IgE levels of $235 \mathrm{IU} / \mathrm{mL}$ (normal: $<173 \mathrm{IU} /$ $\mathrm{mL})$, Aspergillus-specific IgE levels of $5.49 \mathrm{UA} / \mathrm{mL}$ (normal: $<0.35 \mathrm{UA} / \mathrm{mL}$ ), positive for Aspergillusspecific precipitin and negative for serum antigen of Aspergillus spp.

Chest radiography showed consolidation in the left middle lung field. Chest CT revealed highattenuation mucus (HAM), a typical finding in allergic bronchopulmonary aspergillosis (ABPA), and central bronchiectasis (figure 1). We performed a transbronchial biopsy of the mucus plugs in the left upper lobe. Pathological findings showed remarkable eosinophil infiltration with CharcotLeyden crystals, and branching hyphae on Grocott stain (figure 2). In the culture of bronchial lavage fluid, Aspergillus fumigatus was detected.

Consequently, the patient fulfilled 8 of 10 components in the criteria for allergic bronchopulmonary mycosis (ABPM) by the Japan ABPM Research Programme. ${ }^{1}$ Therefore, we confirmed the diagnosis of ABPA, and subsequently, prednisolone with tapering was administered. After the treatment, her symptoms, eosinophilia and

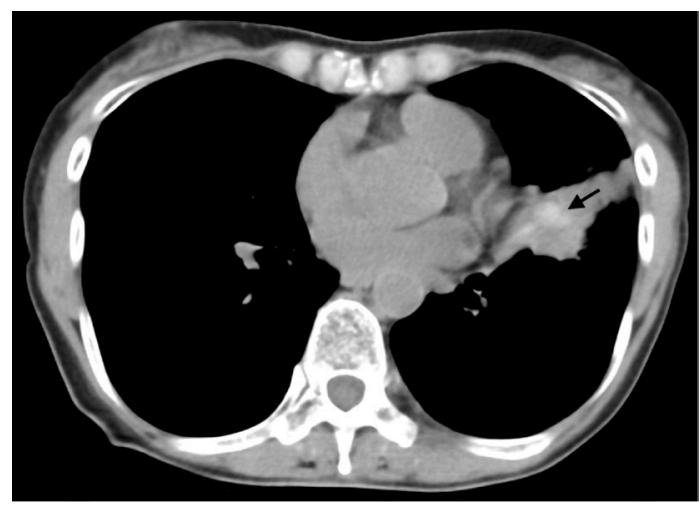

Figure 1 Chest CT shows high-attenuation mucus (arrow).

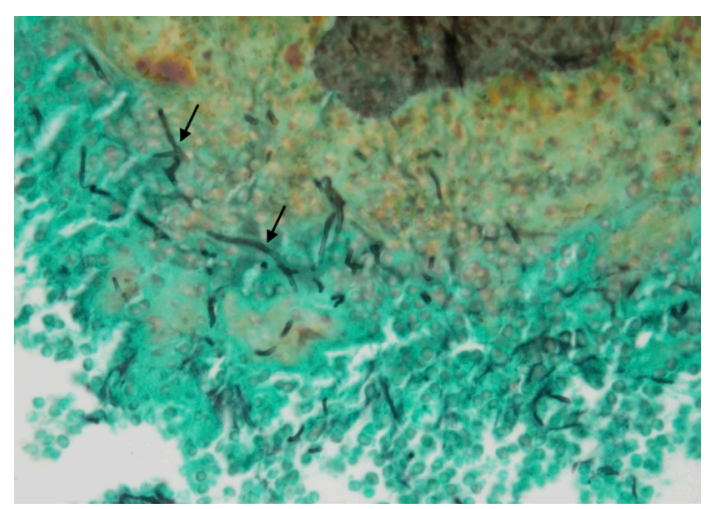

Figure 2 Grocott stain for biopsied specimen of mucus plugs shows branching hyphae (arrows).

consolidation on chest radiography were gradually improved.

ABPM is a disease caused by an allergic reaction to fungi in the lower respiratory tract, especially those caused by Aspergillus spp are called ABPA. ${ }^{2}$ There are several clinical diagnostic criteria for ABPM, including Rosenberg-Patterson criteria proposed in $1977,{ }^{3}$ the International Society for Human and Animal Mycology (ISHAM) criteria in $2013^{4}$ and the Japan ABPM Research Programme criteria in 2020 .

The Rosenberg-Patterson criteria have a high specificity of $98.4 \%$ but a low sensitivity of $49.2 \%$, while the ISHAM criteria have a sensitivity of $82.7 \%$ and a specificity of $86.8 \%$. In contrast, the sensitivity and specificity of the Japan ABPM Research Programme criteria are $94.4 \%$ and $90.0 \%$, respectively, indicating that ABPM can be diagnosed with high accuracy. ${ }^{1}$

ABPM often shows mucoid impaction, and its differential diagnosis includes endobronchial lesions or foreign bodies, bronchial atresia and bronchiectasis due to various causes. ${ }^{5}$ HAM is defined as mucus plugs with higher densities than paravertebral muscles on high-resolution CT, and the CT density value of 70 Hounsfield units is an

\section{Learning points}

Allergic bronchopulmonary mycosis can be diagnosed by Japan Allergic Bronchopulmonary Mycosis Research Programme criteria with higher accuracy than other criteria.

- High-attenuation mucus is an important finding in the early diagnosis of allergic bronchopulmonary mycosis. 
adequate cut-off value. ${ }^{6}$ It has been assumed that iron, manganese and calcium produced by fungi in the mucus may cause higher densities. ${ }^{6}$ The sensitivity and specificity of HAM for ABPA are reported as $39.7 \%$ and $100 \%$, respectively. ${ }^{7}$ HAM is an important finding in the early diagnosis of ABPM.

Acknowledgements We thank Editage (www.editage.com) for English language editing.

Contributors $\mathrm{SI}$ and HS drafted the manuscript. TT and KN revised the manuscript.

Funding The authors have not declared a specific grant for this research from any funding agency in the public, commercial or not-for-profit sectors.

Competing interests None declared.

Patient consent for publication Consent obtained directly from patient(s)

Provenance and peer review Not commissioned; externally peer reviewed.

ORCID iD

Hiroshi Sugimoto http://orcid.org/0000-0002-2053-8858

\section{REFERENCES}

1 Asano K, Hebisawa A, Ishiguro T, et al. New clinical diagnostic criteria for allergic bronchopulmonary aspergillosis/mycosis and its validation. J Allergy Clin Immunol 2021:147:1261-8.

2 Knutsen AP, Bush RK, Demain JG, et al. Fungi and allergic lower respiratory tract diseases. J Allergy Clin Immunol 2012;129:280-91.

3 Rosenberg M, Patterson R, Mintzer R, et al. Clinical and immunologic criteria for the diagnosis of allergic bronchopulmonary aspergillosis. Ann Intern Med 1977;86:405-14.

4 Agarwal R, Chakrabarti A, Shah A, et al. Allergic bronchopulmonary aspergillosis: review of literature and proposal of new diagnostic and classification criteria. Clin Exp Allergy 2013:43:850-73

5 Agarwal R, Aggarwal AN, Gupta D. High-attenuation mucus in allergic bronchopulmonary aspergillosis: another cause of diffuse high-attenuation pulmonary abnormality. AJR Am J Roentgenol 2006:186:904

6 Phuyal S, Garg MK, Agarwal R, et al. High-Attenuation mucus impaction in patients with allergic bronchopulmonary aspergillosis: objective criteria on high-resolution computed tomography and correlation with serologic parameters. Curr Prob/ Diagn Radiol 2016;45:168-73.

7 Agarwal R, Maskey D, Aggarwal AN, et al. Diagnostic performance of various tests and criteria employed in allergic bronchopulmonary aspergillosis: a latent class analysis. PLoS One 2013;8:e61105.

Copyright 2021 BMJ Publishing Group. All rights reserved. For permission to reuse any of this content visit

https://www.bmj.com/company/products-services/rights-and-licensing/permissions/

BMJ Case Report Fellows may re-use this article for personal use and teaching without any further permission.

Become a Fellow of BMJ Case Reports today and you can:

- Submit as many cases as you like

- Enjoy fast sympathetic peer review and rapid publication of accepted articles

- Access all the published articles

Re-use any of the published material for personal use and teaching without further permission

Customer Service

If you have any further queries about your subscription, please contact our customer services team on +44 (0) 2071111105 or via email at support@bmj.com.

Visit casereports.bmj.com for more articles like this and to become a Fellow 